\title{
Metallomics
}

Cite this: Metallomics, 2014, 6,1591

Received 11th March 2014, Accepted 11th April 2014

DOI: $10.1039 / \mathrm{c} 4 \mathrm{mt} 00075 \mathrm{~g}$

www.rsc.org/metallomics

\section{Detailed analysis of pro-apoptotic signaling and metabolic adaptation triggered by a $\mathrm{N}$-heterocyclic carbene-gold(I) complex $\dagger$}

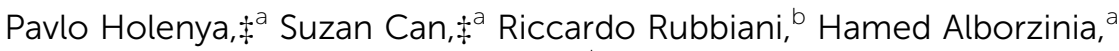 \\ Anja Jünger, ${ }^{a}$ Xinlai Cheng, ${ }^{a}$ Ingo Ott ${ }^{b}$ and Stefan Wölf $\star^{\star a}$
}

\begin{abstract}
Due to their broad spectrum of biological activity and antiproliferative effect on different human cancer cell lines, gold compounds have been in the focus of drug research for many years. Gold(I)-N-heterocyclic carbene complexes are of particular interest, because of their stability, ease of derivatization and clear cytotoxicity in cancer cells. To obtain a more detailed view of the molecular mechanisms underlying their cellular activity, we used a novel gold(I)-N-heterocyclic carbene complex, [triphenylphosphane-(1,3-diethyl5-methoxy-benzylimidazol-2-ylidene)]gold(I) iodide and investigated changes in cellular signaling pathways using quantitative signal transduction protein microarray analysis. We also analyzed changes in cell metabolism in a time-dependent manner by on-line metabolic measurements and used isolated mitochondria to elucidate the direct effects on this cell organelle. We found strong cytotoxic effects in cancer cells, accompanied by an immediate and irreversible loss of mitochondrial respiration as well as by a crucial imbalance of the intracellular redox state, resulting in apoptotic cell death. ELISA microarray analysis of signal transduction pathways revealed a time-dependent up-regulation of pro-apoptotic signaling proteins, e.g. p38 and JNK, whereas pro-survival signals that are directly linked to the thioredoxin system were down-regulated, which pinpoints to thioredoxin reductase as a central target of the compound. Further results suggest that DNA is an indirect target of the compound. Based on our findings, we outline a signaling model for the molecular mechanism underlying the antiproliferative activity of the gold(I) $-\mathrm{N}$ heterocyclic carbene complex investigated, which provides a good general model for the known pattern of cell death induced by this class of substances.
\end{abstract}

\section{Introduction}

Cisplatin and other platinum agents have been playing an important role in cancer chemotherapy during the last few decades. However, due to strong side effects and the resistance phenomenon there is an increasing interest in the development of non-cisplatin-type metal complexes as anticancer drug candidates. Their considerable structural and stereochemical variety, high stability and broad coordination properties introduce organometallic substances as promising alternative sources of novel therapeutic and diagnostic agents. ${ }^{1-4}$

\footnotetext{
${ }^{a}$ Department of Biology, Institut für Pharmazie und molekulare Biotechnologie, Ruperto-Carola University of Heidelberg, Im Neuenheimer Feld 364, D-69120 Heidelberg, Germany. E-mail: wolfl@uni-hd.de

${ }^{b}$ Institute of Medicinal and Pharmaceutical Chemistry, Technische Universität Braunschweig, Beethovenstrasse 55, D-38106 Braunschweig, Germany

$\dagger$ Electronic supplementary information (ESI) available. See DOI: 10.1039/ c4mt00075g

\$ These authors contributed equally to this work.
}

Organometallic compounds with a coordinated gold atom in the oxidation states +1 and +3 have been in focus of several studies demonstrating a strong cytotoxicity in different cancer cell lines. ${ }^{5-8}$ Gold compounds can trigger cell death mechanisms by targeting various cellular systems: through interaction with DNA similarly to platinum compounds, ${ }^{9}$ by affecting mitochondria and redox balance, ${ }^{10,11}$ modulating cell cycle control, ${ }^{12}$ proteolysis ${ }^{13}$ and signal transduction. ${ }^{14,15}$ Still, detailed mechanisms of action, which seem to vary depending on the carrier ligand, remain unclear. Thioredoxin reductase (TrxR) appears to be a common molecular target of gold compounds as gold displays a high affinity to selenol groups. $^{16,17}$ This central enzyme of the mammalian antioxidant system maintains a reducing environment by transmitting the electron flux from NADPH generated by the pentose phosphate pathway to its substrate thioredoxin (Trx), which is involved in the redox control of different signaling pathways. ${ }^{18}$

A hallmark of highly proliferative cancer cells is an increased production of reactive oxygen species (ROS). ${ }^{19}$ This results in oxidative stress, which can cause damage to several mitochondrial components and macromolecules leading to senescence and 
apoptosis. $^{20}$ Inhibition of TrxR or the structurally similar glutathione reductase (GR) leads to accumulation of oxidized glutathione and Trx and reduces the capacity of the most important antioxidant systems in cancer cells to counteract ROS mediated damage. ${ }^{20,21}$

In addition to this direct role in the modulation of the cellular redox state, Trx directly interacts with other proteins associated with cell death mechanisms. Its reduced form binds and inactivates apoptosis signal-regulating kinase 1 (ASK1). ${ }^{18,22}$ In the presence of ROS, the oxidized Trx form is released and activates ASK1 to mediate apoptosis via the JNK and p38 pathways. $^{20}$ p53, a transcription factor controlling pro-apoptotic genes, is also regulated by $\mathrm{Trx}^{21,23}$

Gold(I)-N-heterocyclic carbene (NHC) complexes have been increasingly reported as promising anticancer agents. ${ }^{24-32}$ Due to the NHC ligands, these substances show high stability and ease of derivatization, that allow for a rapid adjustment of physicochemical properties. Recent studies have demonstrated a strong selective TrxR inhibition by several gold(I)-NHC complexes in vitro as first reported by Hickey et al. in $2008 .^{25,26,29,31,32}$ Experiments on cancer cells revealed a high increase of ROS formation and imbalances in cellular metabolism, including reduced mitochondrial activity, which resulted in apoptotic cell death. ${ }^{5,24-29}$

In order to understand the mechanism of cell death induction by gold(I)-NHC complexes, we exemplarily investigated the influence of the novel complex [triphenylphosphane-(1,3-diethyl-5-methoxybenzylimidazol-2-ylidene)]gold(I) iodide ( $\mathrm{Au}(\mathrm{I}) \mathrm{NHC}$ ) on cytotoxicity, cell metabolism and mitochondrial activity. Au(I)NHC is an organometallic complex of the $\mathrm{Au}(\mathrm{I})(\mathrm{NHC})$ (phosphane) type, which we had suggested as a particularly promising organometallic group in one of our previous reports. ${ }^{26}$ Here we present the quantitative and timeresolved analysis of concentration-dependent effects of $\mathrm{Au}(\mathrm{I}) \mathrm{NHC}$ on several signaling pathways using ELISA microarrays. We found that $\mathrm{Au}(\mathrm{I}) \mathrm{NHC}$ triggers cell death in cancer cells targeting different cellular systems. Similarly to other substances of this class, $\mathrm{Au}(\mathrm{I}) \mathrm{NHC}$ inhibits TrxR thereby affecting cellular redox homeostasis, alters mitochondrial respiration and membrane permeability and evidently causes DNA damage. As a consequence, we observed a sustained activation of several pro-apoptotic signaling pathways and concomitant down-regulation of pro-survival signals. Based on our results, we suggest a molecular mechanism-based model explaining the cell death induction triggered by the investigated complex.

\section{Results and discussion}

\section{Au(I)NHC selectively inhibits TrxR}

TrxR is a very specific intracellular target for antitumor agents $^{18,20,21,33,34}$ and in particular several established gold(I) complexes (e.g. auranofin) have been reported as strong inhibitors. ${ }^{16,17}$ In mammalian cells, TrxR is a large homodimeric selenoenzyme that belongs to the disulfide oxidoreductase family. ${ }^{33}$ Two main isoforms play a key role in regulating the overall intracellular redox balance: the cytosolic TrxR1 and the mitochondrial TrxR2. ${ }^{18}$ Inhibition of either Trx system can lead to activation of apoptosis. ${ }^{20}$ Binding of gold(I) complexes to TrxR is related to a direct metal coordination to its active site containing a selenocysteine residue on the flexible C-terminal arm. ${ }^{11,16}$

Taking these facts into consideration, $\mathrm{Au}(\mathrm{I}) \mathrm{NHC}$ was tested for its ability to inhibit the activity of purified total TrxR (Fig. 1, panel a). To evaluate selectivity, the assay was also performed using another enzyme of the cellular antioxidant system, glutathione reductase (GR), which maintains glutathione in its reduced state and is closely related to TrxR in structure and function. Au(I)NHC was able to inhibit TrxR in the low micromolar range $\left(\mathrm{IC}_{50}=\right.$ $1.95 \mu \mathrm{M})$, whereas the gold-free benzimidazolium iodide exhibited no inhibitory activity. The inhibitory effect of $\mathrm{Au}(\mathrm{I}) \mathrm{NHC}$ on GR activity with $\mathrm{IC}_{50}=49.9 \mu \mathrm{M}$ was considerably weaker. These findings demonstrate that $\mathrm{Au}(\mathrm{I}) \mathrm{NHC}$ selectively targets TrxR, which contains, in contrast to GR, a thiol-selenol C-terminal residue in its active site. Moreover, the coordinated gold atom is essential for the high affinity binding to TrxR as the metal free organic ligand did not inhibit TrxR or GR (Fig. 1). In general, the observed effects are similar to those already reported for other gold(I)-NHC complexes, ${ }^{25,26}$ whose strong capability to inhibit TrxR varies depending on their coordinated ligands.

Although TrxR is the only cellular enzyme able to reduce Trx, it can also act on many other low molecular weight disulfide and non-disulfide substrates. ${ }^{20}$ Therefore, the inhibition of TrxR by $\mathrm{Au}(\mathrm{I}) \mathrm{NHC}$ affects the cellular redox state in many directions simultaneously.

\section{Antiproliferative activity}

Since Trx and TrxR are overexpressed in many tumors to control their aberrant redox state, ${ }^{34}$ we subsequently investigated the influence of $\mathrm{Au}(\mathrm{I}) \mathrm{NHC}$ on the growth and proliferation of various cancer cell lines. Valuable antiproliferative effects were

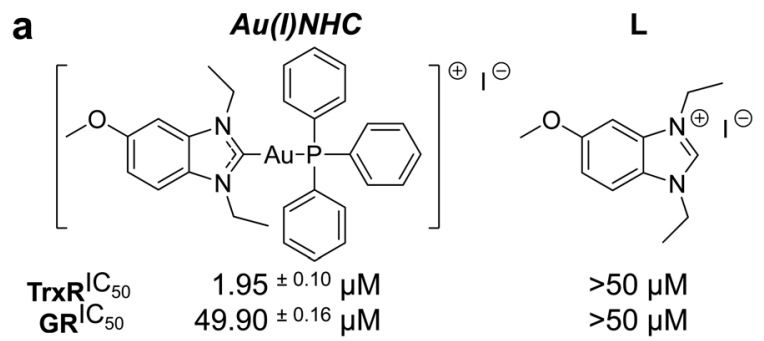

b

\begin{tabular}{c|c} 
Cell line & $I_{50} \pm$ SE $(\mu \mathrm{M})$ \\
\hline HT29 & $3.445 \pm 0.597$ \\
MCF7 & $1.602 \pm 0.168$ \\
Panc1 & $1.729 \pm 0.047$
\end{tabular}

Fig. 1 Structures and inhibitory effects of the investigated substances. (a) Au(I)NHC structure and the inhibitory effect on TrxR and GR compared to the gold-free benzimidazolium iodide (L). (b) Cell viability of different cell lines upon treatment with Au(I)NHC. 
observed for HT29, MCF7 and Panc1 cells (Fig. 1, panel b) with $\mathrm{IC}_{50}$ values in the micromolar range.

\section{Cancer cell metabolism is irreversibly affected by $\mathrm{Au}(\mathrm{I}) \mathrm{NHC}$}

TrxR inhibition may be an important but not the only effect of treatment in cancer cells. To analyze cellular metabolism and morphological changes of cancer cells treated with $\mathrm{Au}(\mathrm{I}) \mathrm{NHC}$, we used the real-time biosensor chip system Bionas 2500. The system measured $\mathrm{pH}$ change and oxygen consumption reflecting cellular glycolytic and mitochondrial activity, respectively, and cellular impedance linked to cell morphological changes as well as cell-cell and cell-surface adhesion. ${ }^{35}$ All three parameters showed an immediate change in HT29 cells treated with $\mathrm{Au}(\mathrm{I}) \mathrm{NHC}$ (Fig. 2). Oxygen consumption was inhibited almost immediately after exposure to all applied concentrations, which conveys that cellular respiration was completely blocked even by $1.0 \mu \mathrm{M} \mathrm{Au}(\mathrm{I}) \mathrm{NHC}$. The acidification rate increased drastically in the beginning, followed by a transition period of a few hours and an abrupt decrease denoting a complete glycolysis elimination. The time- and concentration-dependent profiles of glycolysis modulation appear to be evident: higher concentrations of $\mathrm{Au}(\mathrm{I}) \mathrm{NHC}$ achieved a more rapid and shorter transition from increased glycolysis (for $10 \mu \mathrm{M}$ this has occurred already after $2.5 \mathrm{~h}$ of treatment) to an entire block, whereas transition peaks appeared later on the time scale at lower concentrations. Cell impedance increased slightly in the first $2 \mathrm{~h}$ of treatment followed by a rapid decrease in a concentration-dependent manner. Remarkably, all three parameters showed irreversible changes since a 10 h-recovery period with medium without $\mathrm{Au}(\mathrm{I}) \mathrm{NHC}$ did not restore cellular homeostasis.

All together, real-time measurements revealed that $\mathrm{Au}(\mathrm{I}) \mathrm{NHC}$ induced a rapid and irreversible alteration of cellular metabolism having cell death as the obvious outcome. In this analysis mitochondria appeared to be a clear cellular target of the substance: due to the rapid respiration deadlock, cells shift the energy metabolism from oxidative phosphorylation to glycolysis, mirrored in an increased acidification rate, as a compensatory mechanism. A slight increase in cell impedance most probably reflected the generation of stress fibers. The following drastic change in impedance clearly indicated that cells were losing their membrane functionality and detached from the chip surface reflecting the time frame of apoptosis initiation.

\section{Au(I)NHC directly targets mitochondria}

The immediate block of respiration in colon cancer cells raised the question of whether mitochondria could be affected directly by the $\mathrm{Au}(\mathrm{I}) \mathrm{NHC}$ treatment or whether their physiological functions are suppressed indirectly through other cellular mechanisms or e.g. DNA damage. To ascertain this, isolated mouse liver mitochondria were used to determine organelle functionality. We observed a rapid time- and concentration-dependent suppression of mitochondrial respiratory activity (Fig. 3, panel a), whereas the known uncoupling agent carbonyl cyanide 3-chlorophenylhydrazone (CCCP) and the complex I inhibitor rotenone clearly increased or blocked
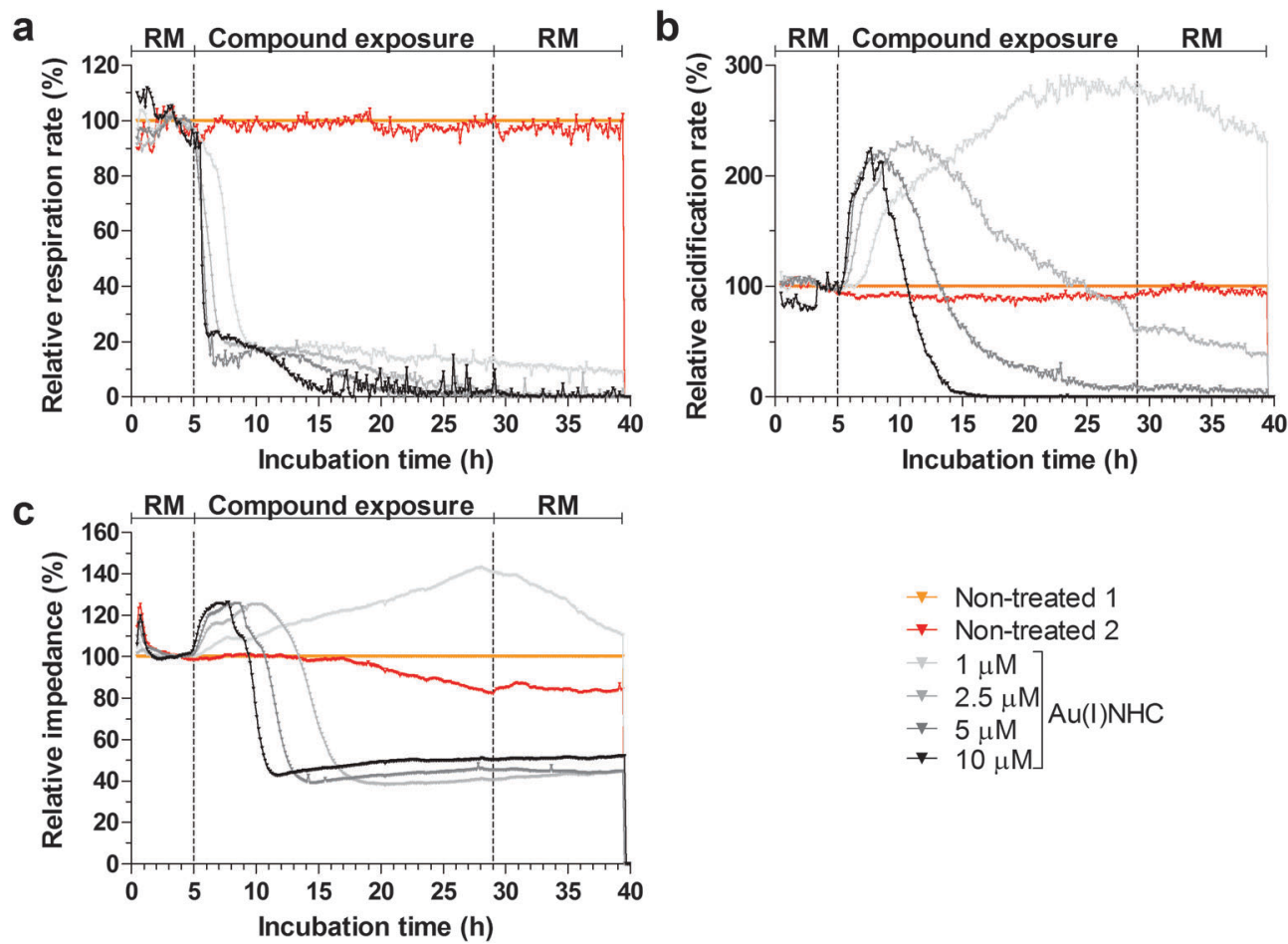

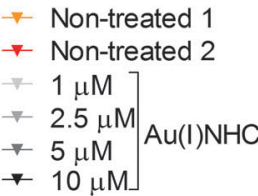

Fig. 2 Real-time changes of metabolic parameters in HT29 cells upon treatment with Au()NHC. (a) Cellular respiration (oxygen levels in the medium). (b) Activity of glycolysis measured as changes in extracellular acidification. (c) Cell adhesion and morphology presented as changes in cell layer impedance. RM (running medium) stands for compound-free medium. 

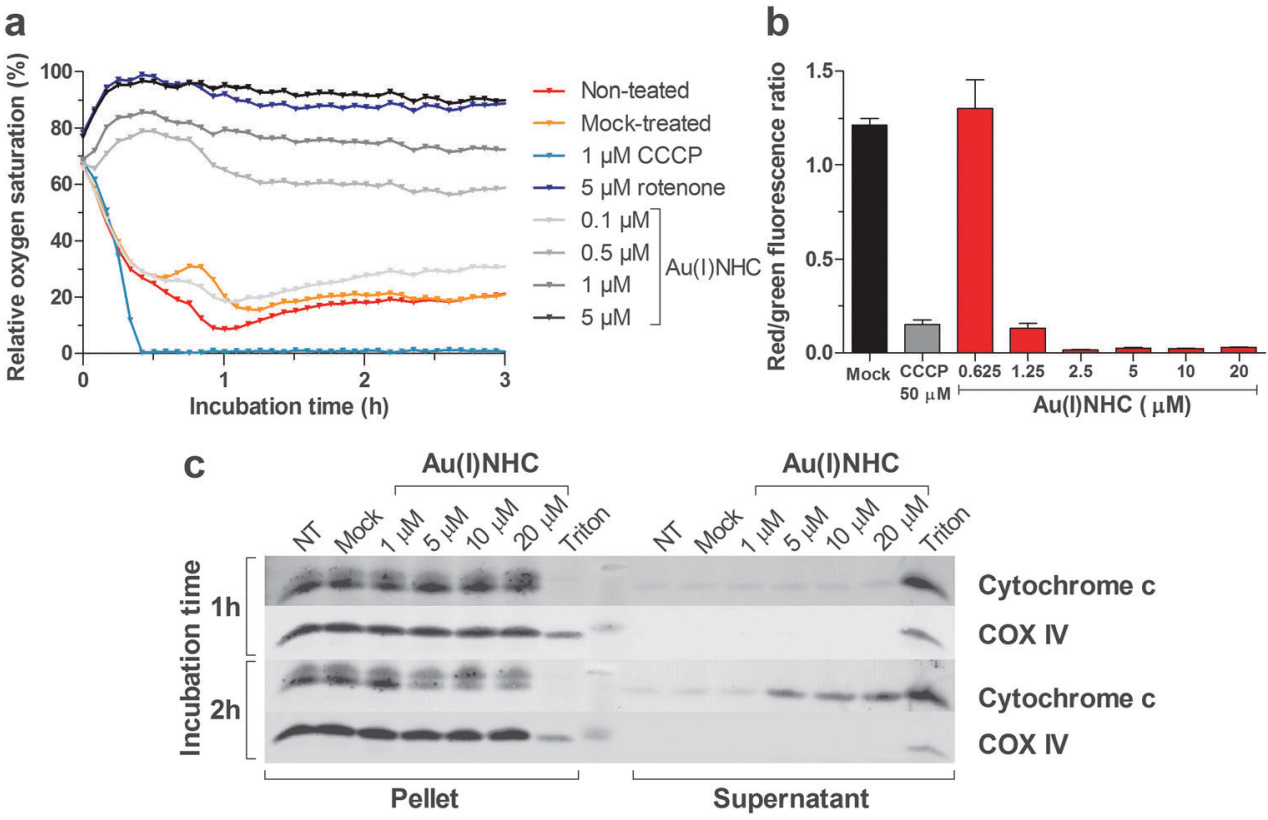

Fig. 3 Effects of $\mathrm{Au}(\mathrm{I}) \mathrm{NHC}$ treatment on mitochondria. (a) Respiration of isolated mouse liver mitochondria depicted as a decrease of oxygen saturation over time. Mock-treated samples contained $0.1 \%(v / v)$ DMF. CCCP $(1 \mu \mathrm{M})$ was used as a control of the maximal oxygen consumption $(0 \%$ oxygen in the respiration buffer). The respiratory chain complex I inhibitor rotenone was used as a positive control of respiration inhibition (oxygen concentration close to $100 \%$ ). (b) Mitochondrial membrane potential in Jurkat cells presented as JC- $1_{\text {aggregated }} / \mathrm{JC}-1_{\text {monomeric }}$ fluorescence ratio. Mock stands for mocktreated cells $(0.1 \%(\mathrm{v} / \mathrm{v}) \mathrm{DMF})$. The proton uncoupling reagent CCCP $(50 \mu \mathrm{M})$ was used as a positive control. (c) Cytochrome $c$ release from isolated mouse liver mitochondria. Mock-treated samples contained 0.1\% (v/v) DMF. Triton X-100 (1\% (v/v)) was used as a positive control for outer membrane permeabilization. Cytochrome $c$ oxidase subunit IV (COX IV) detection was used as a control of protein loading and as an indicator for the intactness of the inner mitochondrial membrane.

respiration, respectively. Notably, $5 \mu \mathrm{M}$ of $\mathrm{Au}(\mathrm{I}) \mathrm{NHC}$ blocked respiration to the same extent as rotenone, which was also applied at $5 \mu \mathrm{M}$.

To examine whether the decrease of the mitochondrial respiratory activity occurred in parallel with the alteration of the inner membrane permeability, the mitochondrial membrane potential $\left(\Delta \Psi_{\mathrm{m}}\right)$ was measured in Jurkat $\mathrm{T}$ lymphocyte cells. We observed a strong decrease of the $\Delta \Psi_{\mathrm{m}}$ value depending on $\mathrm{Au}(\mathrm{I}) \mathrm{NHC}$ concentration applied to the cells (Fig. 3, panel b). These findings indicate that mitochondria are directly targeted by Au(I)NHC. This is in good agreement with a previous report, where we confirmed high mitochondrial accumulation of a structural analogue of $\mathrm{Au}(\mathrm{I}) \mathrm{NHC} .{ }^{26}$ Comparing the observed effects in both experiments with those of the control substance CCCP, which strongly decreases $\Delta \Psi_{\mathrm{m}}$ in cells, we can conclude that Au(I)NHC acts as an inhibitor of the oxidative phosphorylation modulating the electron flow along the respiratory chain.

$\mathrm{Au}(\mathrm{I}) \mathrm{NHC}$ also directly promotes mitochondrial outer membrane permeabilization. Using immunoblot, we detected a gradual increase of cytochrome $c$ released from isolated mouse liver mitochondria after $2 \mathrm{~h}$ of treatment (Fig. 3, panel c), whereas levels of this intermembrane protein decreased in the mitochondrial fraction.

\section{TrxR inhibition by Au(I)NHC leads to oxidative stress}

Since mitochondria are considered to be a source of reactive oxygen species, and the gold complex had been shown to be a strong inhibitor of TrxR, we analyzed ROS formation in Jurkat T lymphocytes and K562 leukemia cells, in response to Au(I)NHC treatment after $24 \mathrm{~h}$ and $48 \mathrm{~h}$ (Fig. 4). Both cell lines displayed a strong increase in ROS levels, exceeding the ROS production induced by the positive control camptothecin, an established cytotoxic inhibitor of topoisomerase I. The increase of ROS also correlated with applied Au(I)NHC concentrations.

The profile of ROS production shows that inhibition of TrxR and inhibition of mitochondrial respiration within $1 \mathrm{~h}$ by the $\mathrm{Au}(\mathrm{I}) \mathrm{NHC}$ leads to massive oxidative stress within cells. In aerobic cells, ROS are also produced by the other electron transport chains present in endoplasmic reticulum and nuclear membranes. ${ }^{36}$ Based on our results, we assume that the oxidative stress in response to $\mathrm{Au}(\mathrm{I}) \mathrm{NHC}$ treatment might be achieved due to inhibition of both, cytosolic TrxR1 and mitochondrial TrxR2, although the separate impact of the inhibition of either enzyme isoforms on the induction of oxidative stress is still ambiguous.

\section{Au(I)NHC induces apoptosis in cancer cells}

Until now we have described several events induced by Au(I)NHC in cancer cells: strong cytotoxic effects, loss of mitochondrial respiration and later of glycolytic activity, an imbalance in the intracellular redox state, and finally cell death. All these conditions favor apoptosis as the main way for cells to die. ${ }^{20}$ To address this hypothesis, we performed flow cytometry analysis of annexin V/propidium iodide-stained Jurkat cells. ${ }^{37}$ The cell-state 
a

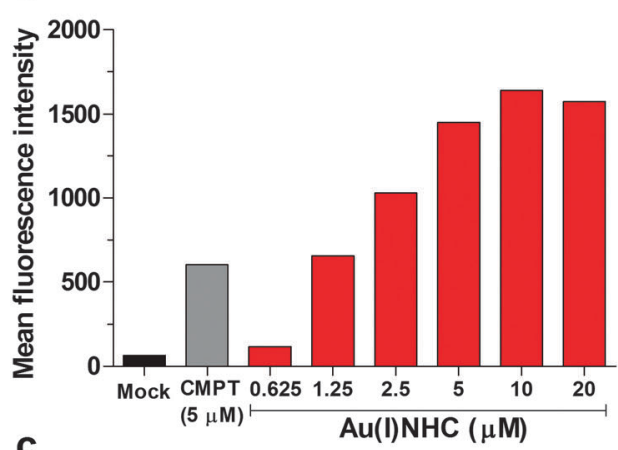

C

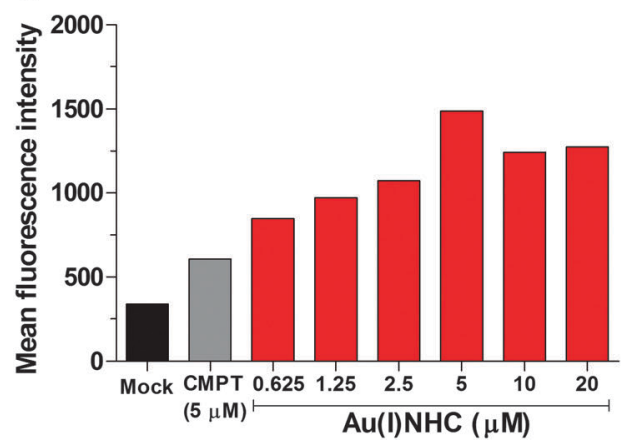

b
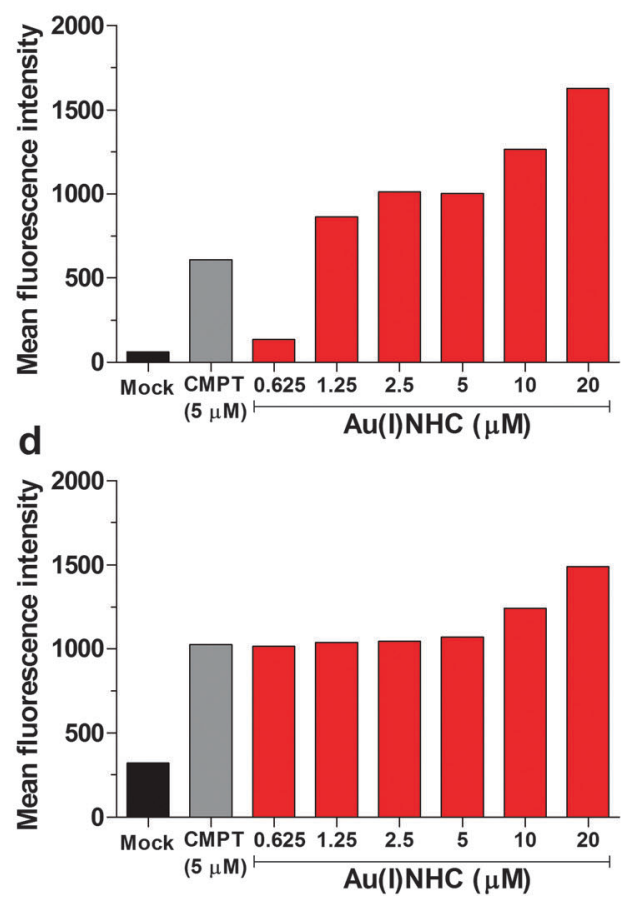

Fig. 4 Intracellular ROS formation in response to Au()NHC treatment. (a and b) ROS formation in Jurkat cells after $24 \mathrm{~h}$ and $48 \mathrm{~h}$ treatment, respectively. (c and d) ROS levels in K562 cells after $24 \mathrm{~h}$ and $48 \mathrm{~h}$ treatment, respectively. Mock stands for mock-treated cells (0.1\% (v/v) DMF). Camptothecin (CMPT) was used as a positive control for ROS induction.
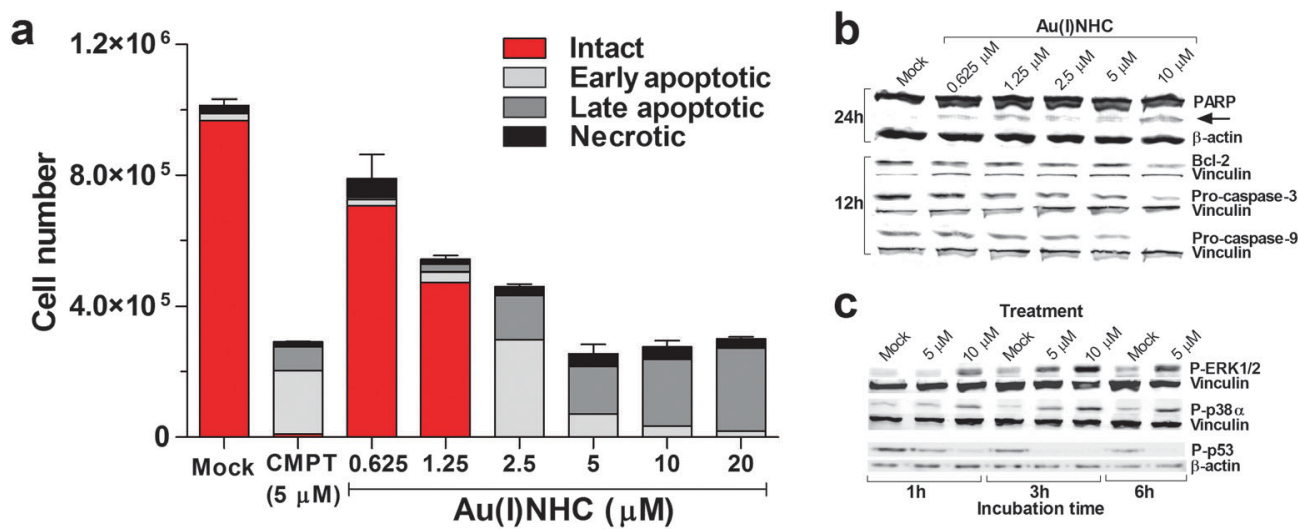

Fig. 5 Apoptosis induction and modulation of cell signaling. (a) Cell state distributions of Jurkat cells treated with Au()NHC. Mock stands for mocktreated cells $(0.1 \%(\mathrm{v} / \mathrm{v}) \mathrm{DMF})$. The topoisomerase I inhibitor camptothecin was used as a positive control for apoptosis induction. Counted cell populations stained with annexin $\vee$ only, both dyes, propidium iodide and annexin $V$ at the same time or with propidium iodide only reflected the number of early apoptotic, late apoptotic and necrotic cells, respectively. (b) PARP cleavage, decrease of the anti-apoptotic mitochondrial Bcl2 and activation of the caspase cascade in HT29 cells during Au(I)NHC-induced cell death. Arrow indicates the cleaved $89 \mathrm{kDa}$ fragment of PARP. $\beta$-Actin or vinculin was analyzed in the same experiment as internal controls. (c) Induction of phospho-ERK1/2 (T202/Y204) and phospho-p38 (T180/Y182) and reduction of phospho-p53 (S15) in HT29 cells in response to Au()NHC treatment.

distributions after $48 \mathrm{~h}$ treatment with $\mathrm{Au}(\mathrm{I}) \mathrm{NHC}$ showed a strong dose-dependent antiproliferative effect in comparison to the control (Fig. 5, panel a). Whereas significant numbers of viable cells were present after incubation with $0.625-1.25 \mu \mathrm{M}$ $\mathrm{Au}(\mathrm{I}) \mathrm{NHC}$, early and late apoptotic cells dominated in the higher concentration ranges. Only negligible populations of necrotic cells were detected for all concentrations of the compound.
Further we examined whether caspase cascade activation is involved in cell death processes. As shown in Fig. 5 (panel b), the degradation of procaspase- 3 and procaspase- 9 was observed after $12 \mathrm{~h}$ of treatment in HT29 cells. Treatment of cells with $\mathrm{Au}(\mathrm{I}) \mathrm{NHC}$ also induced poly-ADP-ribose polymerase (PARP) cleavage, with the accumulation of the $89 \mathrm{kDa}$ fragment. Finally, we observed a reduction of the anti-apoptotic Bcl-2 

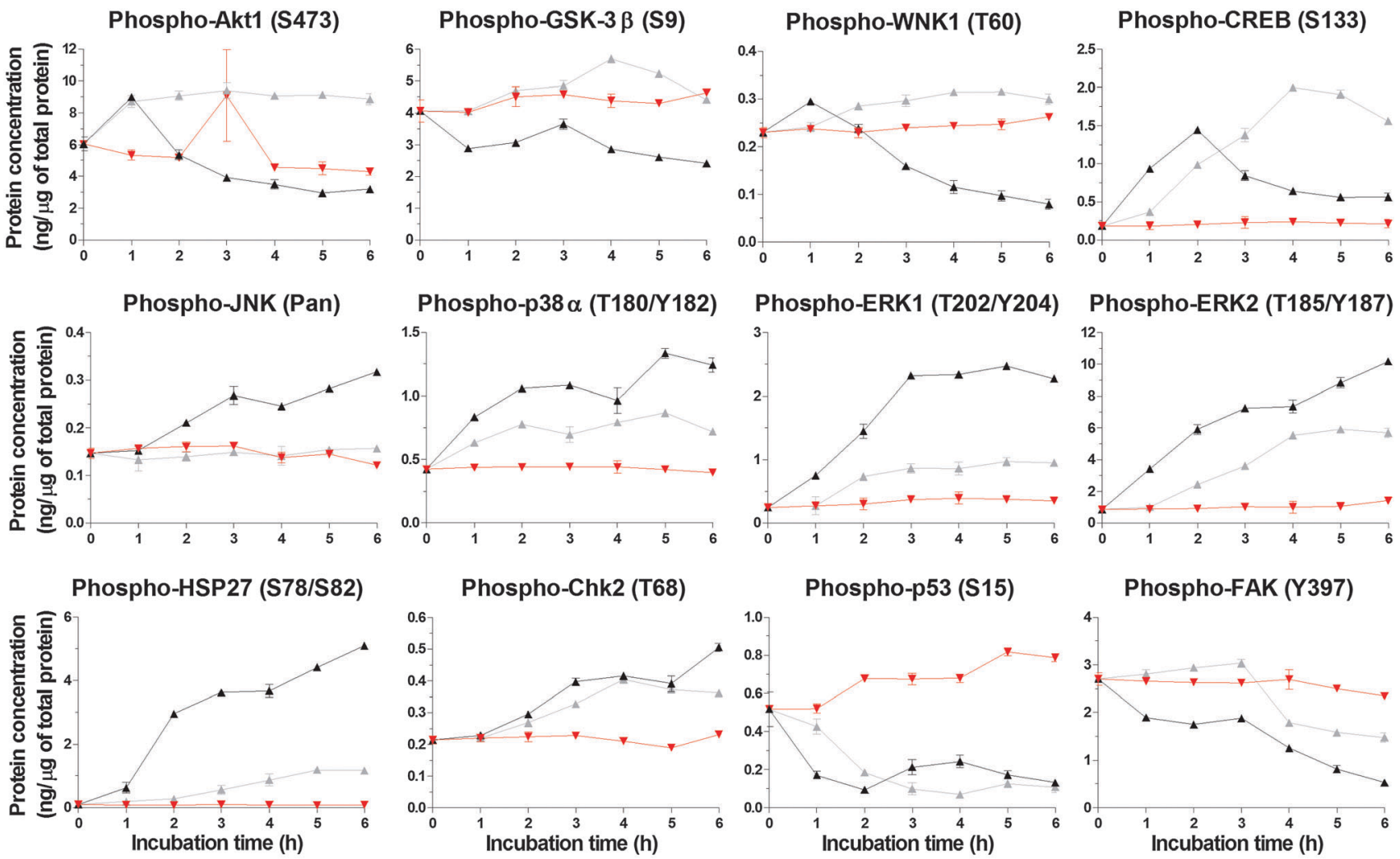

* Mock-treated $\$ 5 \mu \mathrm{MAu}(\mathrm{I}) \mathrm{NHC} \neq 10 \mu \mathrm{MAu}(\mathrm{I}) \mathrm{NHC}$

Fig. 6 ELISA microarray measurements of absolute phosphoprotein concentrations in HT29 cells upon treatment with Au(I)NHC.

protein indicating the activation of the mitochondria-dependent apoptotic pathway.

In summary, all described events confirm the apoptotic cell death in response to treatment.

\section{Analyzing Au( $\mathrm{I}) \mathrm{NHC}$ impacts on cell signaling}

To gain a more detailed view of cell death induced by the $\mathrm{Au}(\mathrm{I}) \mathrm{NHC}$ treatment, we analyzed a panel of key signaling proteins in their phosphorylated states covering different signal transduction pathways. For this reason we used protein immunoblot and ELISA microarrays, designed in our lab, that allow simultaneous quantitative analysis of up to 25 modified signaling proteins in a single sample. ${ }^{38}$ Using this tool, we analyzed HT29 cells incubated in a time course experiment $(0-6 \mathrm{~h})$ with two concentrations of the compound, 5 and $10 \mu \mathrm{M}$, respectively (Fig. 5 , panel c; Fig. 6), or treated for $2 \mathrm{~h}$ with an increasing concentration of $\mathrm{Au}(\mathrm{I}) \mathrm{NHC}$ (Fig. S1, ESI $\dagger$ ).

We observed a significant time- and concentration-dependent sustained activation of all important mitogen activated protein kinases (MAPKs). The levels of phospho-ERK1 (T202/Y204), phospho-ERK2 (T185/Y187), phospho-p38 $\alpha$ (T180/Y182) and phospho-JNK (total) increased two- to twenty-fold upon treatment with $10 \mu \mathrm{M} \mathrm{Au}(\mathrm{I}) \mathrm{NHC}$ in comparison to mock-treated $(0.1 \% \mathrm{v} / \mathrm{v} \mathrm{DMF})$ samples. Our analysis also revealed a strong activation of the chaperone HSP27 as well as the DNA damage associated kinase Chk2. Interestingly, several signaling proteins, among which the key protein of PI3-kinase signaling, Akt1, the ERK5 signaling upstream modulator WNK1, and the cAMP-sensitive transcription factor CREB, exhibited a transient activation profile: while $5 \mu \mathrm{M} \mathrm{Au}(\mathrm{I}) \mathrm{NHC}$ induced a slight increase in their phosphorylation during the $6 \mathrm{~h}$ time scale analyzed, the higher concentration of the compound $(10 \mu \mathrm{M})$ rapidly changed from induction after $1-2 \mathrm{~h}$ of treatment to a sustained decrease after longer incubation. In comparison to Akt1, the levels of phospho-GSK-3 $\beta$ (S9) and phospho-FAK (Y397) displayed a more rapid concentration-dependent transition from increase to decrease. Finally, we could observe a fast and significant loss of phosphorylated p53 with both compound concentrations.

To prove that apoptotic cell death is mainly mediated by the inhibition of TrxR, we treated HT29 cells with a specific TrxRinhibitor auranofin using an identically designed time course experiment. We found that changes in cell signaling induced by $4 \mu \mathrm{M}$ auranofin (HT29: $\mathrm{IC}_{50}=1.9 \mu \mathrm{M}$ ) were of very similar character and grade as signaling profiles generated by $\mathrm{Au}(\mathrm{I}) \mathrm{NHC}$-treatment on the same time scale (Fig. S2, ESI $\dagger$ ).

\section{Mechanism of Au(I)NHC-induced cell death}

Integrating all our findings, we generated a signaling model that explains the mechanism of action (Fig. 7). We could show that the $\mathrm{Au}(\mathrm{I}) \mathrm{NHC}$-complex analyzed selectively inhibited TrxR and that the gold(I) atom was essential for this activity. This fact is consistent with previous studies identifying TrxR as a target of gold compounds and 


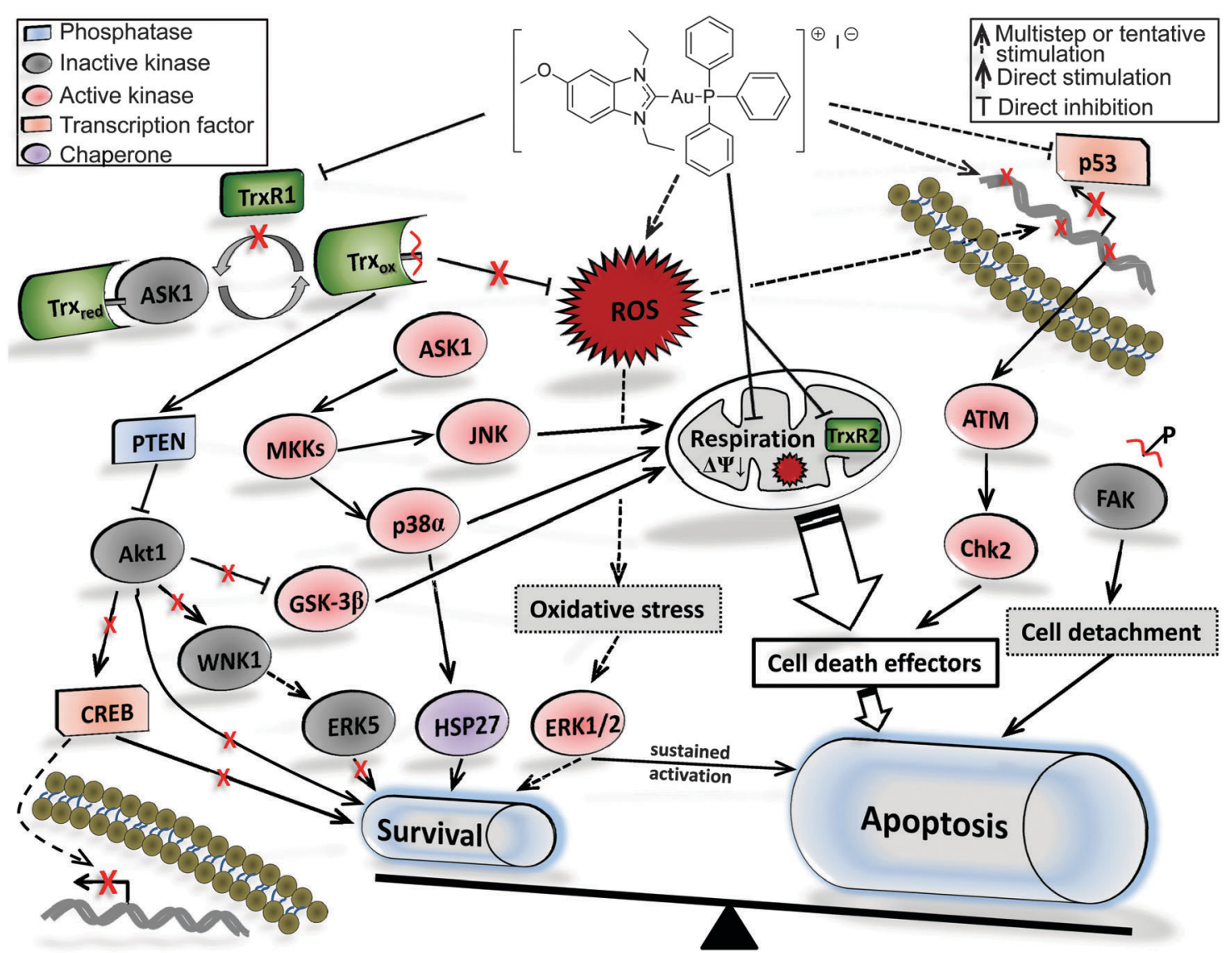

Fig. 7 Signaling model underlying $\mathrm{Au}(\mathrm{I}) \mathrm{NHC}$-induced cell death.

in particular gold(I)-NHC complexes. ${ }^{11,17,24-26,31} \mathrm{Trx}$ is the main substrate of TrxR in both cytoplasm and mitochondria, and decreased TrxR activity leading to a diminished pool of reduced (active) Trr. ${ }^{18}$ This in turn causes an inability of cells to get rid of endogenous ROS. We have already mentioned that TrxR inhibition by itself shifts the cellular redox state towards more oxidized conditions since this enzyme reduces a broad variety of substrates. Furthermore, it is known that metal ions can be a source of exogenous ROS, ${ }^{39}$ and $\mathrm{Au}(\mathrm{I}) \mathrm{NHC}$ molecules might have a separate impact on the overall imbalance of the cellular redox status. Indeed, we observed a dramatic increase in cellular ROS levels leading to an oxidative catastrophe.

Using kinetic analysis of signal transduction, we were able to demonstrate that in a short term perspective (few min to several h) $\mathrm{Au}(\mathrm{I}) \mathrm{NHC}$ considerably modulated cell signaling. On the one hand, besides their direct action on macromolecules, ROS are considered to be important second messengers in deathassociated signal transduction. ${ }^{40}$ This is in good accordance with our observation of a strong and sustained activation of the ERK1/2 pathway, associated with oxidative stress, and high ROS as a wellknown trigger of this pathway. ${ }^{39,40}$ Although ERK1/2 are generally known as pro-survival markers, they can also stimulate the proapoptotic pathway and serve as important stress markers in the cell. ${ }^{18}$ Furthermore, it has been demonstrated that ROS are potent inducers of JNK that is critical for cell fate determination, ${ }^{41}$ which also coincides with our findings.
On the other hand, Trx interacts with many proteins involved in redox-signaling pathways. The reduced form of Trx acts as a negative regulator of ASK1. ${ }^{18,40}$ Upon strong oxidative stress or when reduction of Trx is inhibited, ASK1 is released and activates several MAPK kinases, such as MKK 3, 4, 6 and 7, which phosphorylate and activate pro-apoptotic JNK and p38 MAPK. ${ }^{20,41}$ Both kinases, when activated by ASK1, reportedly associate with mitochondria, inactivate anti-apoptotic and activate pro-apoptotic proteins. ${ }^{18,42}$ Our results revealed a rapid activation of both, JNK and p38, consistent with the described mechanism.

Oxidized Trx activates another important regulator of apoptosis, the phosphatase and tensin homolog (PTEN). ${ }^{18}$ PTEN stimulates apoptosis by inhibiting Akt1, responsible for cell growth and proliferation. ${ }^{18}$ This is also reflected in our microarray measurements demonstrating a transient and dose-dependent loss of the pro-survival signal of Akt1.

We also found reduced phosphorylation of GSK-3 $\beta$, a downstream target of Akt1. In its active (dephosphorylated) form, GSK-3 $\beta$ targets the anti-apoptotic Bcl-2-like protein Mcl-1 for ubiquitination and thereby contributes to mitochondrial membrane permeabilization (MMP). ${ }^{42}$ Besides GSK-3 $\beta$, several studies have suggested that high ROS and activated JNK are known as cytosolic signals leading to MMP and resulting in apoptosis. ${ }^{41,42}$ The loss of mitochondrial membrane potential in our experiments is directly related to MMP and most probably results from all three signals. 
Although the transcription factor CREB can be a substrate for various cellular kinases, ${ }^{43}$ it plays an important role in survival signaling and is a regulatory target of Akt1. ${ }^{44,45}$ When phosphorylated (activated) by Akt1, CREB induces expression of genes promoting proliferation, differentiation, adaptation and survival in many cell types. ${ }^{43}$ It has been shown that PTEN de-phosphorylates CREB independently of the PI3K/AKT pathway inhibiting cell growth and proliferation. ${ }^{46}$ Consistent with this mechanism, pro-survival CREB phosphorylation occurred transiently, comparable to Akt1, with a peak after $2 \mathrm{~h}$ of treatment $(10 \mu \mathrm{M} \mathrm{Au}(\mathrm{I}) \mathrm{NHC})$ followed by an abrupt loss of phosphorylated CREB, which concurred with the activation of pro-apoptotic signaling.

WNK1, another direct target of Akt1 ${ }^{47,48}$ also showed a similar transient activation profile further supporting this hypothesis. WNK1 can activate ERK5 by an MEKK2/3-dependent mechanism, ${ }^{49}$ which has been implicated in anti-apoptotic signaling, inducing p53 ubiquitination ${ }^{50}$ and Bad phosphorylation..$^{51}$

Phosphorylation of HSP27 on Ser 78 and Ser 82 is another indicator of cellular response to stress. This chaperone can be directly phosphorylated by p38 on both sites ${ }^{52}$ and regulates cell survival under stress conditions by degradation of denaturated proteins $^{53}$ or by interfering with activation of pro-apoptotic procaspase-9. ${ }^{54}$ Among some other specialized functions, HSP27 has also been shown to activate the pentose phosphate pathway to reduce ROS, another activity directly linked to p38. ${ }^{55}$

Several authors postulated DNA damage as still another mechanism of anticancer activity of gold containing compounds. ${ }^{9,20,56}$ We could clearly see activation of signaling that could be associated with DNA damage. Au(I)NHC induced Chk2, known to transduce DNA damage signals. ${ }^{57}$

To our surprise, phosphorylated p53 was depleted upon treatment. Although it is known that HT29 colon cancer cells have a mutant p53 and can undergo p53-independent apoptosis, ${ }^{58}$ we had observed earlier that upstream signals still control p53 phosphorylation. $^{59}$ This suggests that damage triggered by $\mathrm{Au}(\mathrm{I}) \mathrm{NHC}$ is significantly different from other DNA damage events. Since it is known that p53 can promote DNA repair, cell cycle arrest or apoptosis, the lack of p53 phosphorylation upon $\mathrm{Au}(\mathrm{I}) \mathrm{NHC}$ treatment could provide a therapeutic advantage in treating cancers containing wild-type p53 where p53 mediated survival must be avoided.

Finally, Au(I)NHC treatment strongly inhibited the autophosphorylation of FAK at Y397. This is a clear pro-apoptotic signal that is known to promote the turn-over of focal contacts and contribute to cell rounding that results in anoikis. ${ }^{60}$ The mode of FAK dephosphorylation closely resembles the kinetic impedance change profile, which is the direct benchmark of cell adhesion and is mediated by FAK.

\section{Experimental}

\section{Synthetic chemistry}

[Triphenylphosphane-(1,3-diethyl-5-methoxy-benzylimidazol-2ylidene)]gold(I) iodide and the ligand precursor 1,3-diethyl-5methoxy-benzimidazolium iodide were synthesized according to an established procedure as outlined by Rubbiani et al. ${ }^{26}$
Structures were confirmed by NMR (Bruker DRX-400 AS) and mass spectrometry (LTQ XL Thermo Electron Corporation) and the purity was determined by elemental analysis (Flash EA112 Thermo Quest Italia).

1,3-Diethyl-5-methoxy-benzimidazolium iodide. 5-Methoxybenzimidazole $(0.74 \mathrm{~g}, 5.0 \mathrm{mmol})$ was dissolved in toluene and reacted with ethyl iodide $(1.2 \mathrm{ml}, 15.0 \mathrm{mmol})$ in the presence of $\mathrm{Na}_{2} \mathrm{CO}_{3}(0.53 \mathrm{~g}, 5.0 \mathrm{mmol})$ for $24 \mathrm{~h}$ in reflux under vigorous stirring. The solvent of the resulting suspension was removed under reduced pressure, and the residue was resuspended in dichloromethane and filtered to remove the sodium bicarbonate. The filtrate was evaporated under reduced pressure, the residue was resuspended in tetrahydrofuran and filtered to give the pure product. Yield: $1.23 \mathrm{~g}$ (3.7 mmol, 74\%) brown powder; ${ }^{1} \mathrm{H}$ NMR (DMSO-d $)$ : (ppm) $1.54\left(\mathrm{~m}, 6 \mathrm{H}, \mathrm{CH}_{3}\right), 3.92(\mathrm{~s}, 3 \mathrm{H}$, $\left.\mathrm{OCH}_{3}\right), 4.48\left(\mathrm{~m}, 4 \mathrm{H}, \mathrm{CH}_{2}\right), 7.28\left(\mathrm{dd}, 1 \mathrm{H},{ }^{3} \mathrm{~J}=9.1 \mathrm{~Hz},{ }^{4} \mathrm{~J}=2.4 \mathrm{~Hz}\right.$, $\mathrm{ArH}_{6}$ ), 7.61 (d, 1H, $\left.{ }^{4} J=2.4 \mathrm{~Hz}, \mathrm{ArH}_{4}\right), 7.97$ (d, $1 \mathrm{H},{ }^{3} J=9.1 \mathrm{~Hz}$, $\mathrm{ArH}_{7}$ ), 9.68 (s, 1H, $\mathrm{ArH}_{2}$ ); ${ }^{13} \mathrm{C}$ NMR (DMSO-d ${ }_{6}$ ): (ppm) 14.2 $\left(\mathrm{CH}_{3}\right), 42.0\left(\mathrm{CH}_{2}\right), 56.3\left(\mathrm{OCH}_{3}\right), 96.0$ (ArC), 114.4 (ArC), 116.4 (ArC), 125.2 (ArC), 132.1 (ArC), $140.6\left(\mathrm{ArC}_{2}\right), 158.6\left(\mathrm{ArC}_{5}\right)$; elemental analysis for $\mathrm{C}_{10} \mathrm{H}_{13} \mathrm{~N}_{2} \mathrm{O} \cdot \mathrm{I}$ (\% calculated/found): $\mathrm{C}$ (43.39/43.55) H (5.16/5.20) N (8.43/8.41).

[Triphenylphosphane-(1,3-diethyl-5-methoxybenzylimidazol-2-ylidene)]gold(I) iodide. 1,3-Diethyl-5-methoxybenzimidazolium iodide $(0.066 \mathrm{~g}, 0.2 \mathrm{mmol})$ was dissolved in dichloromethane in the presence of $\mathrm{Na}_{2} \mathrm{CO}_{3}(0.021 \mathrm{~g}, 0.2 \mathrm{mmol})$, heated for 10 minutes at $50{ }^{\circ} \mathrm{C}$ and reacted with chloro triphenyl-phosphane gold(I) ( $0.099 \mathrm{~g}, 0.2 \mathrm{mmol})$ under vigorous stirring for $60 \mathrm{~h}$. The solution was filtered to remove the $\mathrm{Na}_{2} \mathrm{CO}_{3}$, evaporated under reduced pressure and purified through column chromatography (silica column, eluent dichloromethane-methanol 97.5/2.5\%). Yield: $0.093 \mathrm{~g}$ (0.11 mmol, 59\%) brown powder; ${ }^{1} \mathrm{H}$ NMR $\left(\mathrm{CDCl}_{3}\right)$ : (ppm) $1.64\left(\mathrm{~m}, 6 \mathrm{H}, \mathrm{CH}_{3}\right), 3.95\left(\mathrm{~s}, 3 \mathrm{H}, \mathrm{OCH}_{3}\right), 4.60\left(\mathrm{q}, 2 \mathrm{H},{ }^{3} \mathrm{~J}=\right.$ $7.3 \mathrm{~Hz}, \mathrm{CH}_{2}$ ), 4.66 (q, 2H, $\left.{ }^{3} J=7.3 \mathrm{~Hz}, \mathrm{CH}_{2}\right), 7.45(\mathrm{~m}, 18 \mathrm{H}$, $\mathrm{ArH}) ;{ }^{13} \mathrm{C}$ NMR $\left(\mathrm{CDCl}_{3}\right)$ : (ppm) $16.0\left(\mathrm{CH}_{3}\right), 44.2\left(\mathrm{CH}_{2}\right), 56.5$ $\left(\mathrm{OCH}_{3}\right), 95.1$ (ArC), 112.2 (ArC), 114.2 (ArC), 127.3 (ArC), 128.8 (d, $\operatorname{PArC}_{1^{\prime}}$ ), 130.6 (d, $\operatorname{PArC}_{2^{\prime}}$ ), 132.2 (d, $\operatorname{PArC}_{3^{\prime}}$ ), 133.9 (ArC), 134.1 (d, $\left.\operatorname{PArC}_{4^{\prime}}\right), 158.1\left(\operatorname{ArC}_{5}\right), 190.2\left(\operatorname{ArC}_{2}\right) ;{ }^{31} \mathrm{P}$ NMR $\left(\mathrm{CDCl}_{3}\right)$ : (ppm) 32.9; MS (ESI): $663[\mathrm{M}-\mathrm{I}]^{+}$; m.p. $202{ }^{\circ} \mathrm{C}$; elemental analysis for $\mathrm{C}_{30} \mathrm{H}_{31} \mathrm{AuN}_{2} \mathrm{OP} \cdot \mathrm{I}$ (\% calc./found): $\mathrm{C}$ (45.59/45.87) $\mathrm{H}(3.95 / 4.02) \mathrm{N}(3.54 / 3.81)$.

\section{TrxR/GR inhibition assay}

The assay was performed as described by Rubbiani et $a .^{26}$

\section{Cell culture}

HT29, MCF7 and Panc1 cells (ATCC) were maintained in DMEM High Glucose (PAA Laboratories) containing 10\% fetal calf serum (FCS, PAA Laboratories) at $37{ }^{\circ} \mathrm{C}$ with $5 \% \mathrm{CO}_{2}$ and passaged twice a week according to standard procedures.

Jurkat and K562 cells (DSMZ) were maintained in RPMI 1640 medium (PAA Laboratories) supplemented with 10\% FCS (PAA Laboratories) under the standard growth conditions. 


\section{Cell proliferation assay}

Cell proliferation inhibition was measured using the MTT assay. HT29 cells were plated in 96-well plates at a density of 4000 cells per well and incubated for $48 \mathrm{~h}$ under standard cell culture conditions. For treatment ( $48 \mathrm{~h}$ ), a stock solution of the gold complex in dimethylformamide (DMF) was freshly prepared, diluted with cell culture medium to the indicated concentrations (final DMF concentration: $0.1 \%(\mathrm{v} / \mathrm{v})$ ) and added to cells (four replicates, $200 \mu \mathrm{l}$ per well). Mock-treated cells were incubated with an equal concentration of DMF only.

\section{Online measurement of cell metabolism}

Morphological changes and physiological parameters of living cells were studied on a Bionas 2500 biosensor chip system (Bionas) as described by Alborzinia et al. ${ }^{35}$ The whole timeresolved experiment to test the metabolic activity of the gold complex included the following flow stages: (a) $5 \mathrm{~h}$ of equilibration with running medium (RM), (b) $27.5 \mathrm{~h}$ of exchange cycles of RM with a freshly dissolved gold complex, (c) $10 \mathrm{~h}$ of recovery with RM only, and (d) $1 \mathrm{~h}$ of removal of cells from the chip surface with $0.2 \%(\mathrm{v} / \mathrm{v})$ Triton X-100 to obtain a negative control signal for normalization.

\section{Intracellular ROS formation}

K562 and Jurkat cells were treated with the indicated concentrations of the gold complex for $24 \mathrm{~h}$ and $48 \mathrm{~h}$ under standard growth conditions. Then, cells were centrifuged at $1500 \mathrm{rpm}$, each sample was resuspended in $250 \mu \mathrm{l}$ of flow cytometry buffer $\left(1 \%\right.$ BSA $(\mathrm{m} / \mathrm{v})$ in D-PBS) (final cell density of $\sim 10^{6}$ cells $\mathrm{ml}^{-1}$ ) and treated for 15 min with $25 \mu \mathrm{M}$ dihydroethidium (SigmaAldrich) at room temperature in the dark. Finally, the fluorescence intensity was measured using a FACS Calibur flow cytometer (Becton Dickinson) at $488 \mathrm{~nm}$ excitation and 564$606 \mathrm{~nm}$ emission wavelengths reflecting the total intracellular ROS levels.

\section{Cell death detection using annexin V/propidium iodide}

Jurkat cells were incubated with the indicated serial dilutions of the gold complex under standard growth conditions for $48 \mathrm{~h}$ and stained with Annexin V-FITC and Propidium Iodide Staining Solution (both from eBioscience $\mathrm{GmbH}$ ) according to manufacturer's protocol. The fluorescence intensity was measured by flow cytometry at $488 \mathrm{~nm}$ excitation and 515$545 \mathrm{~nm}$ emission wavelengths for Annexin V-FITC and at $488 \mathrm{~nm}$ excitation and 564-606 $\mathrm{nm}$ emission wavelengths for propidium iodide.

Fluorescently labeled Annexin V detects levels of phosphatidylserine expressed on the cell surface (characteristic of apoptosis). Propidium iodide is a membrane impermeant and stains DNA only when the cell membrane is damaged. Thus, counted cell populations stained with Annexin V only reflected the cells that undergo apoptosis but their cell membranes are still intact (early apoptotic). Cells stained with both dyes at the same time or with propidium iodide only were counted as late apoptotic and necrotic, respectively. ${ }^{37}$

\section{Mitochondria isolation from mouse liver cells}

Mitochondria were isolated from mouse liver cells (mouse line C57BL/6, wildtype) by Dounce homogenization and differential centrifugation. ${ }^{61}$ The amount of total protein was measured using Bradford assay.

\section{Measurement of mitochondrial respiration}

The oxygen consumption by intact mitochondria was measured using the OxoPlate sensor system (PreSens) in a 96-well plate format. The oxygen sensor fluorescence intensity was detected at $540 \mathrm{~nm}$ excitation and $650 \mathrm{~nm}$ emission wavelengths. The reference emission was measured at $590 \mathrm{~nm}$ and the signal ratio $650 \mathrm{~nm} / 590 \mathrm{~nm}$ reflected the oxygen partial pressure in the solution. The kinetic fluorescence measurements were performed for $400 \mathrm{~min}$ with $5 \mathrm{~min}$ intervals using a Tecan Safire 2 reader (Tecan) at $37{ }^{\circ}$ C. A breathable membrane (Diversified Biotech) was used to seal the plates during signal detection. $5 \mu \mathrm{M}$ rotenone (Sigma-Aldrich, inhibitor of respiratory chain complex I) and $1 \mu \mathrm{M}$ carbonyl cyanide 3-chlorophenylhydrazone (CCCP, Sigma-Aldrich, uncoupling agent, capable of increasing the electron flow through the respiratory chain) served as controls.

\section{Measurement of mitochondrial membrane potential}

Jurkat cells were treated with the indicated serial dilutions of the gold complex under standard growth conditions for $24 \mathrm{~h}$. The assay was performed as described by Rubbiani et al. ${ }^{26}$

\section{Quantitative analysis of signaling proteins}

HT29 cells were seeded in 6-well plates $(35 \mathrm{~mm})$ at a density of $2 \times 10^{5}$ cells per well and were grown for $48 \mathrm{~h}$ under standard cell culture conditions to $60-70 \%$ confluence. The cells were treated with indicated concentrations of freshly diluted gold complex or auranofin (final DMF concentration: $0.1 \%(\mathrm{v} / \mathrm{v})$ ) without medium replacement. For mock-treatment, cells were incubated with an equal concentration of DMF only. Sample collection and quantitative measurements of signaling proteins were performed as described by Holenya et al. ${ }^{38}$ Quantification of kinetic data was made using KOMA software. ${ }^{59}$ The final results were calculated from 2 independent experiments.

\section{Protein immunoblot}

Total protein extract samples $(20 \mu \mathrm{g})$ were separated by $10 \%$ SDS-PAGE and transferred to PVDF membranes (Millipore) at $0.02 \mathrm{~A} \mathrm{~cm}^{-2}$ for $1 \mathrm{~h}$. Primary antibodies (Cell Signaling) were diluted to $1: 1000$ using TBS-Tween $(0.1 \%$ Tween-20 (v/v), 5\% nonfat milk (m/v) in TBS, pH 7.5) was added and incubated overnight with gentle shaking at $4{ }^{\circ} \mathrm{C}$. Secondary antibodies (horseradish peroxidase-conjugated anti-mouse or anti-rabbit IgG; KPL) were diluted and incubated with the membrane according to manufacturer's protocol. Protein bands were made visible using a Western Lightning $^{\mathrm{TM}}$ kit (Perkin Elmer) and signals were detected using a LAS 3000 Imaging System (Fuji). Signal quantification was performed using AIDA Image Analysis Software 4 (Raytest). 


\section{Conclusions}

We performed a detailed investigation of the biological activity of gold(I)-N-heterocyclic carbene complexes using a novel derivative $\mathrm{Au}(\mathrm{I}) \mathrm{NHC}$ with a strong cytotoxic potential. In summary, our results show that $\mathrm{Au}(\mathrm{I}) \mathrm{NHC}$ induces apoptosis in cancer cells targeting at least three different pathways. As already reported for gold(I)-NHC complexes, ${ }^{24-26,31,32} \mathrm{Au}(\mathrm{I}) \mathrm{NHC}$, presented here, inhibits thioredoxin reductase and induces a crucial imbalance in cellular redox homeostasis, although it remains open which isoforms, cytoplasmic, mitochondrial or both, are responsible for the observed effects. Au(I)NHC appears to directly affect mitochondria by rapid and irreversible inhibition of their respiratory activity. Finally, our findings also revealed several early signaling events associated with DNA damage, indicating that DNA is another, but an indirect target of $\mathrm{Au}(\mathrm{I}) \mathrm{NHC}$. All perturbations together lead to an enormous irreversible cell stress with an accumulation of several persistent pro-apoptotic signals resulting in programmed cell death.

Our results demonstrate a high therapeutic potential of gold(I) complexes and underline that quantitative analysis of key factors of signaling pathways and of cellular metabolic activity can be used to obtain a detailed model of the cellular response to small molecules.

\section{Acknowledgements}

We thank Alere Technologies GmbH (Jena, Germany) for providing microarray platforms. We also thank J. Lochead and M. Klevanski for their great help. This work was sponsored by Deutsche Forschungsgemeinschaft through FOR 630 and Bundesinstitut für Risikobewertung through FK3 1329-468 and FK3 1328-448.

\section{Notes and references}

1 G. Gasser, I. Ott and N. Metzler-Nolte, J. Med. Chem., 2011, 54, 3-25.

2 C. G. Hartinger, N. Metzler-Nolte and P. J. Dyson, Organometallics, 2012, 31, 5677-5685.

3 T. Gianferrara, I. Bratsos and E. Alessio, Dalton Trans., 2009, 7588-7598.

4 A. L. Noffke, A. Habtemariam, A. M. Pizzarro and P. J. Sadler, Chem. Commun., 2012, 48, 5219-5246.

5 S. Nobili, E. Mini, I. Landini, C. Gabbiani, A. Casini and L. Messori, Med. Res. Rev., 2010, 30, 550-580.

6 S. J. Berners-Price and A. Filipovska, Metallomics, 2011, 9, 863-873.

7 T. Zou, C. T. Lum, S. S. Chui and C. M. Che, Angew. Chem., Int. Ed., 2013, 52, 2930-2933.

8 C. Gabbiani, A. Casini and L. Messori, Gold Bulletin, Springer, Berlin, Heidelberg, 2007, vol. 40, issue 1, pp. 73-81.

9 V. Milacic, D. Fregona and Q. P. Dou, Histol. Histopathol., 2008, 23, 101-108.
10 A. Meyer, C. P. Bagowski, M. Kokoschka, M. Stefanopoulou, H. Alborzinia, S. Can, D. H. Vlecken, W. S. Sheldrick, S. Wölfl and I. Ott, Angew. Chem., Int. Ed., 2012, 51, 8895-8899.

11 A. Casini and L. Messori, Curr. Top. Med. Chem., 2011, 11, 2647-2660.

12 S. Tu, S. R. Wai-Yin, M. C. Lin, C. J. Tao, B. Zou, Q. Gu, H. F. Kung, C. M. Che and B. C. Wong, Cancer, 2009, 115, 4459-4469.

13 M. Serratrice, F. Edafe, F. Mendes, R. Scopelliti, S. M. Zakeeruddin, M. Grätzel, I. Santos, M. A. Cinellu and A. Casini, Dalton Trans., 2012, 41, 3287-3293.

14 N. H. Kim, M. K. Oh, H. J. Park and I. S. Kim, J. Pharmacol. Sci., 2010, 113, 246-254.

15 A. Nakaya, M. Sagawa, A. Muto, H. Uchida, Y. Ikeda and M. Kizaki, Leuk. Res., 2011, 35, 243-249.

16 A. Bindoli, M. P. Rigobello, G. Scutari, C. Gabbiani, A. Casini and L. Messori, Coord. Chem. Rev., 2009, 253, 1692-1707.

17 S. Gromer, L. D. Arscott, C. H. Williams, R. H. Schirmer and K. Becker, J. Biol. Chem., 1998, 273, 20096-20101.

18 S. Lee, S. M. Kim and R. T. Lee, Antioxid. Redox Signaling, 2013, 18, 1165-1207.

19 R. A. Cairns, I. S. Harris and T. W. Mak, Nat. Rev. Cancer, 2011, 11, 85-95.

20 K. F. Tonissen and G. D. Trapani, Mol. Nutr. Food Res., 2009, 53, 87-103.

21 S. Urig and K. Becker, Semin. Cancer Biol., 2006, 16, 452-465. 22 M. Saitoh, H. Nishitoh, M. Fujii, K. Takeda, K. Tobiume, Y. Sawada, M. Kawabata, K. Miyazono and H. Ichijo, EMBO J., 1998, 17, 2596-2606.

23 P. B. Cassidy, K. Edes, C. C. Nelson, K. Parsawar, F. A. Fitzpatrick and P. Moos, Carcinogenesis, 2006, 27, 2538-2549.

24 L. Oehninger, R. Rubbiani and I. Ott, Dalton Trans., 2013, 42, 3269-3284.

25 R. Rubbiani, I. Kitanovic, H. Alborzinia, S. Can, A. Kitanovic, L. A. Onambele, M. Stefanopoulou, Y. Geldmacher, W. S. Sheldrick, G. Wolber, A. Prokop, S. Wölfl and I. Ott, J. Med. Chem., 2010, 53, 8608-8618.

26 R. Rubbiani, S. Can, I. Kitanovic, H. Alborzinia, M. Stefanopoulou, M. Kokoschka, S. Mönchgesang, W. S. Sheldrick, S. Wölfl and I. Ott, J. Med. Chem., 2011, 54, 8646-8657.

27 M. V. Baker, P. J. Barnard, S. J. Berners-Price, S. K. Brayshaw, J. L. Hickey, B. W. Skelton and A. H. White, Dalton Trans., 2006, 3708-3715.

28 P. J. Barnard, M. V. Baker, S. J. Berners-Price and D. A. Day, J. Inorg. Biochem., 2004, 98, 1642-1647.

29 J. L. Hickey, R. A. Ruhayel, P. J. Barnard, M. V. Baker, S. J. Berners-Price and A. Filipovska, J. Am. Chem. Soc., 2008, 130, 12570-12571.

30 J. Lemke, A. Pinto, P. Niehoff, V. Vasylyeva and N. MetzlerNolte, Dalton Trans., 2009, 7063-7070.

31 E. Schuh, C. Pflüger, A. Citta, A. Folda, M. P. Rigobello, A. Bindoli, A. Casini and F. Mohr, J. Med. Chem., 2012, 55, 5518-5528. 
32 R. Rubbiani, E. Schuh, A. Meyer, J. Lemke, J. Wimberg, N. Metzler-Nolte, F. Meyer, F. Mohr and I. Ott, Med. Chem. Commun., 2013, 4, 942-948.

33 W. Cai, L. Zhang, Y. Song, B. Wang, B. Zhang, X. Cui, G. Hu, Y. Liu, J. Wu and J. Fang, Free Radical Biol. Med., 2012, 52, 257-265.

34 E. S. J. Arnér and A. Holmgren, Semin. Cancer Biol., 2006, 16, 420-426.

35 H. Alborzinia, S. Can, P. Holenya, C. Scholl, E. Lederer, I. Kitanovic and S. Wölfl, PLoS One, 2011, 6, e19714, DOI: 10.1371/journal.pone.0019714.

36 C. Fleury, B. Mignotte and J. L. Vayssière, Biochimie, 2002, 84, 131-141.

37 H. Lecoeur, Exp. Cell Res., 2002, 277, 1-14.

38 P. Holenya, I. Kitanovic, F. Heigwer and S. Wölfl, Proteomics, 2011, 11, 2129-2133.

39 A. T. Y. Lau, Y. Wang and J.-F. Chiu, J. Cell. Biochem., 2008, 104, 657-667.

40 A. Matsuzawa and H. Ichijo, Antioxid. Redox Signaling, 2005, 7, 472-481.

41 H.-M. Shen and Z. Liu, Free Radical Biol. Med., 2006, 40, 928-939.

42 G. Kroemer, L. Galluzzi and C. Brenner, Physiol. Rev., 2007, 87, 99-163.

43 B. Mayr and M. Montminy, Nat. Rev. Mol. Cell Biol., 2001, 2, 599-609.

44 X.-Y. Li, X.-R. Zhan, X.-M. Liu and X.-C. Wang, Biochem. Biophys. Res. Commun., 2011, 404, 711-716.

45 K. Du and M. Montminy, J. Biol. Chem., 1998, 273, 32377-32379.

46 T. Gu, Z. Zhang, J. Wang, J. Guo, W. H. Shen and Y. Yin, Cancer Res., 2011, 71, 2821-2825.
47 Z. Y. Jiang, Q. L. Zhou, J. Holik, S. Patel, J. Leszyk, K. Coleman, M. Chouinard and M. P. Czech, J. Biol. Chem., 2006, 280, 21622-21628.

48 A. C. Vitari, M. Deak, B. J. Collins, N. Morrice, A. R. Prescott, A. Phelan, S. Humphreys and D. R. Alessi, Biochem. J., 2004, 378, 257-268.

49 B. Xu, S. Stippec, L. Lenertz, B.-H. Lee, W. Zhang, Y.-K. Lee and M. H. Cobb, J. Biol. Chem., 2004, 279, 7826-7831.

50 J. H. Lim and C.-H. Woo, Anat. Cell Biol., 2011, 44, 265-273.

51 X. Pi, C. Yan and B. C. Berk, Circ. Res., 2004, 94, 362-369.

52 S. Kostenko and U. Moens, Cell. Mol. Life Sci., 2009, 66, 3289-3307.

53 A. Parcellier, E. Schmitt, S. Gurbuxani, D. Seigneurin-Berny, A. Pance, A. Chantôme, S. Plenchette, S. Khochbin, E. Solary and C. Garrido, Mol. Cell. Biol., 2003, 23, 5790-5802.

54 C. Sarto, P. A. Binz and P. Mocarelli, Electrophoresis, 2000, 21, 1218-1226.

55 C. Cosentino, D. Grieco and V. Costanzo, EMBO J., 2011, 30, 546-555.

56 L. Messori, P. Orioli, C. Tempi and G. Marcon, Biochem. Biophys. Res. Commun., 2001, 281, 352-360.

57 W. P. Roos and B. Kaina, Trends Mol. Med., 2006, 12, 440-450.

58 Y. Lim, Y. Jeong, A. L. Tyner and J. H. Park, Am. J. Physiol.: Gastrointest. Liver Physiol., 2007, 292, 66-75.

59 P. Holenya, F. Heigwer and S. Wölfl, J. Immunol. Methods, 2012, 380, 10-15.

60 O. Ndozangue-Touriguine, J. Hamelin and J. Bréard, Biochem. Pharmacol., 2008, 76, 11-18.

61 R. Yamaguchi, A. Andreyev, A. N. Murphy, G. A. Perkins, M. H. Ellisman and D. D. Newmeyer, Cell Death Differ., 2007, 14, 616-624. 